\title{
Assessing communication skills, self esteem and legal awareness- An interventional study on rural adolescent girls Ludhiana district of Punjab
}

\author{
RITU MAHAL, ASHA CHAWLA AND SHABNAM ANSARI
}

Received: 09.03.2017; Revised: 19.09.2017; Accepted: 05.10.2017

See end of the paper for authors' affiliations SHABNAM ANSARI

Department of Human Development and Family Studies, College of Home

Science, Punjab Agricultural University, LUDHIANA (PUNJAB) INDIA

Email : ansari.shabnam59@

gmail.com
ABSTRACT : The present study was conducted in Issewal, Purian, Chappar, Aliwal and Maharna Kalan in central plain zone Ludhiana district of Punjab, the purpose of the study was to assess level of communication skills, levels of self esteem and knowledge regarding legal awareness of rural adolescent girls and impact of educational intervention on rural adolescent girls. A total of one hundred sixty five girl students were selected, Standardized scales was administered on rural adolescent girls. The pre test was done on rural adolescent girls to know about their level of communication skills, levels of self esteem and view of their legal awareness and it was found that the girls showed increase in their mean scores (communication skills,) improved their level of self esteem, and also gained in knowledge about legal aspects as impact of intervention provided to them in terms of packages, pamphlets, lectures etc.

KEY WORDS: Rural adolescents, Self esteem, Intervention, Education, Legal awareness, Communication skills

- HOW TO CITE THIS PAPER : Mahal, Ritu, Chawla, Asha and Ansari, Shabnam (2017). Assessing communication skills, self esteem and legal awareness- An interventional study on rural adolescent girls Ludhiana district of Punjab. Asian J. Home Sci., 12 (2) : 349-354, DOI: 10.15740/HAS/AJHS/12.2/349-354. 